\title{
Antibacterial therapy of surgical sepsis: modern approaches, views, strategy and prospects
}

\author{
V. V. Vashchuk ${ }^{1}$, V. P. Andriushchenko ${ }^{1}$, T. P. Kyryk ${ }^{1}$, M. I. Kushnirchuk ${ }^{2}$, R. P. Baidala ${ }^{2}$, \\ A. Z. Ivanyshyn ${ }^{2}$, T. V. Khomchenko ${ }^{3}$ \\ ${ }^{1}$ Danylo Halytskyi Lviv National Medical University, \\ ${ }^{2}$ Lviv Hospital in rail transport Branches, \\ ${ }^{3}$ Lviv Regional Center for Pulmonary Health
}

\section{Антибактеріальна терапія хірургічного сепсису: сучасні підходи, погляди, стратегія і перспективи}

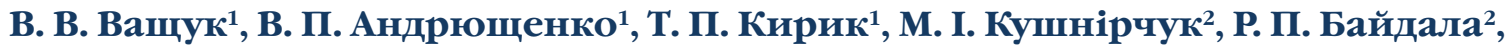 \\ А. 3. Іванишин ${ }^{2}$, Т. В. Хомченко ${ }^{3}$ \\ ${ }^{1}$ Львівський національний медичний університет імені Данила Галицького, \\ 2Львівська клінічна лікарня на залізничному транспорті, \\ 3Львівський обласний центр легеневого здоров'я
}

Sepsis is known as a complex human body's pathological disorder, which requires priority attention. Currently it is becoming a central subject of scientific research. The World Health Organization and the World Health Assembly have adopted the resolution on the importance of unifying of the diagnosis, treatment and prevention of sepsis worldwide. According to epidemiological studies, sepsis accounts from one-third to one-half of hospital mortality in the United States. About 1,400 patients die from sepsis worldwide daily[1].

Due to its high frequency and high pathophysiological, molecular, genetic and clinical complexity sepsis remains a serious challenge for clinicians, researchers, and the intensive care unit.

Sepsis experts focus on diagnosis, intensive care (fluids, vasopressors, ionotropes, blood transfusions, and hemodynamic targets) and infection control (antibiotics and biomarkers of infection). These areas are the keys in further improving of the patient' treatment outcomes.[2-6 ].

Early antibacterial therapy (ABT) is crucial for patients with sepsis and septic shock. Researchers often focus on the time period before the first dose of antibiotics, but subsequent dosing of these drugs is no less important [7]. M. Andersson and co-authors [8] published the results of a study of the effect of time limits on the introduction of the first and second doses of antibiotics on 28-day mortality in patients with sepsis and septic shock. The authors have proposed the criterion of "early appropriate antibiotic treatment" as the introduction of the first dose of adequate antibiotics within one hour from the moment of hospitalization, and the second with a delay of less than $25 \%$ of the recommended interval. The application of the principle of "early appropriate antibiotic treatment" has significantly reduced mortality among high-risk patients.
D. Cudini and co-authors [9] have proposed to quantify the time period, used for prehospital ABT in sepsis, by electronic recording. The average time interval from the moment of the patient contact with the medical stuff to the first administration of an antibiotic have constituted from 74 to $160 \mathrm{~min}$. The authors have noted that minimizing this interval generally has a positive effect on subsequent treatment outcomes. At the same time, the feasibility of prehospital empirical ABT needs further study.

According to other retrospective studies, early administration of ABT correlates with a decrease in mortality in uncomplicated sepsis. Important points in the choice of ABT for empirical therapy of sepsis are: predicting the etiology of the process; spectrum of the drug's action; method of dosing; security profile. Even before obtaining the results of bacteriological data, focusing only on the presumed source of bacterial infection, you can choose an effective scheme of empirical ABT. It is recommended to conduct microbiological monitoring of microflora in each clinic, which allows to compile a "microbiological passport of the hospital" for adequate selection of ABT. Local epidemiological data on the structure of pathogens and their sensitivity to antibiotics should also be taken into account, which may be the basis for the development of local protocols for empirical ABT. For the empirical therapy of sepsis a combination of two antibiotics is most often used, which justifies the following positions: the inability to differentiate the grampositive or gram-negative etiology of the infection according to the clinical picture; high probability of polymicrobial etiology of sepsis; the risk of the resistance development to one of the selected drugs [2, 3, 6, $10-12]$.

In the etiology of sepsis, despite some differences in the results of some studies, we can identify certain patterns. Thus, in case of nonhospital sepsis, there is a dependence of the etiology of the primary focus, while in nosocomial 


\begin{tabular}{|c|c|c|c|c|}
\hline \multicolumn{5}{|c|}{$\begin{array}{l}\text { Leading pathogens of sepsis in different localizations of primary sourcei } \\
\text { (E. Barantsevich et al. [3]) }\end{array}$} \\
\hline \multicolumn{5}{|c|}{ Localization of the primary source of infection } \\
\hline Respiratory tract & Abdominal & Skin / soft tissues & Urinary tract & $\begin{array}{l}\text { Central } \\
\text { Nervous System }\end{array}$ \\
\hline $\begin{array}{l}\text { S. pneumoniae } \\
\text { H. influenzae } \\
\text { Enterobacteriaceae } \\
\text { Legionella spp. } \\
\text { K. pneumoniae } \\
\text { A. baumannii }\end{array}$ & $\begin{array}{l}\text { E. coli } \\
\text { B. fragilis } \\
\text { Klebsiella spp. }\end{array}$ & $\begin{array}{l}\text { S. pyogenes } \\
\text { S. aureus } \\
\text { Enterobacteriaceae } \\
\text { Clostridium spp. } \\
\text { Грампозитивні/ } \\
\text { грамнегативні анаероби } \\
\text { A. baumannii }\end{array}$ & $\begin{array}{l}\text { E. coli } \\
\text { Klebsiella spp. } \\
\text { Enterobacter spp. } \\
\text { Proteus spp. } \\
\text { A. baumannii }\end{array}$ & $\begin{array}{l}\text { S. pneumoniae } \\
\text { N. meningitidis } \\
\text { H. influenzae } \\
\text { L. monocytogenes } \\
\text { E. coli }\end{array}$ \\
\hline
\end{tabular}

\begin{tabular}{|c|c|}
\hline Table 2. & $\begin{array}{l}\text { s of ABT for the infection caused by enterobacteria producing carbapenemase and } \\
\text { acter producing carbapenemase } \\
\text { ed after N.A. Bubnov et al 2016) }\end{array}$ \\
\hline Pathogens & Therapy schemes \\
\hline \multirow{3}{*}{$\begin{array}{l}\text { Klebsiella pneumoniae } \\
\text { E. coli } \\
\text { Acinetobacter spp. } \\
\text { Ps. aeruginosa }\end{array}$} & $\begin{array}{l}\text { When MIC meropenem or doripenem } \leq 8.0 \mu \mathrm{g} / \mathrm{ml} \\
\text { Maximum doses of meropenem }{ }^{1} \text { or doripenem }{ }^{1} \text { (prolonged infusion) }+ \text { polymyxin or tigecycline according } \\
\text { to the sensitivity of the pathogen } \\
\text { Meropenem }{ }^{1} \text { or doripenem }{ }^{1}+\text { sulbactam (ampicillin / sulbactam or cefoperazone / sulbactam) }+ \text { - - tigecycline }{ }^{2} \text {; } \\
\text { ceftazidime / avibactam }\end{array}$ \\
\hline & $\begin{array}{l}\text { When MIC meropenem }>8.0 \mu \mathrm{g} / \mathrm{ml} \\
\text { Polymyxins + tigecycline }{ }^{2}+/ \text { - aminoglycosides }+/ \text { - fosfomycin } \\
\text { Ertapenem }+ \text { meropenem; ceftazidime / avibactam }\end{array}$ \\
\hline & $\begin{array}{l}\text { In the absence of MIC data, meropenem is used } \\
\text { different combinations of } 3 \text { or } 4 \text { antibiotics: } \\
\text { carbapenem }{ }^{1} \text {; tigecycline }{ }^{2} \text {; polymyxins; cefoperazone / sulbactam or ampicillin / sulbactam; fosfomycin; } \\
\text { aminoglycoside; ceftazidime / avibactam }\end{array}$ \\
\hline \multicolumn{2}{|c|}{$\begin{array}{l}\text { Note. } \\
\text { imipenem } 4 \mathrm{~g} \text { ) } ;{ }^{2} \text { - the drug is not active in the infection caused Ps. aeruginosa. }\end{array}$} \\
\hline
\end{tabular}

sepsis, such dependence is usually not observed. At hospital sepsis the etiology depends not so much on the primary source, but the features of medical institution. The defined patterns are grouped in Table 1 [3].

The two thirds of the microorganisms, cultured from the blood of patients with sepsis, are gram-negative flora with the prevalence of K. pneumoniae as the "leader". Another important trend is the growing role of A. baumanii [3].

The dominance of gram-negative flora and frequent detection of multidrug-resistant infection are the reason for more active use of the newest antibiotics. Due to a certain spectrum of antibacterial activity and low resistance, they are suitable for targeted treatment of critically ill patients (escalation monotherapy), although many patients still use combined ABT (Table 2) [3, 13].

An important condition for the successful treatment of patients with sepsis and septic shock is compliance with a number of guidelines and rules, formulated by the results of multicenter studies related to ABT and contain the following essential components [14, 15]:

intravenous antimicrobials should be started immediately after identification of the pathogen and / or within $1 \mathrm{~h}$ after the first symptoms of sepsis / septic shock;

empirical ABT is appropriate in patients with sepsis / septic shock, which includes at least two classes of broad-spec- trum antibiotics to affect a wider range of microorganisms; correction in the form of narrowing of empirical ABT should be carried out in case of identification of the pathogen and its sensitivity and / or in case of clinical improvement;

prophylactic antibiotics are not recommended in patients with severe inflammatory diseases of non-infectious origin (severe pancreatitis, thermal skin burns, etc.);

the antimicrobial dosage strategy should be based on generally accepted pharmacokinetic / pharmacodynamic principles, as well as taking into account of the organ functions and some features of antibiotics in patients with sepsis or septic shock;

combined routine ABT of neutropenic fever / bacteremia is not recommended in the routine practice of clinical departments;

if combined ABT was initially used to treat septic shock, it is recommended that it would be discontinued within the first few days in response to clinical improvement;

the adequate duration of ABT for most infections associated with sepsis / septic shock is 7 to 10 days;

Prolonged use of antibiotics is recommended in patients with a slow clinical response to the therapy, bacteremia caused by Staphylococcus aureus, some fungal and viral infections, as well as in patients with neutropenia; 
shorter courses of ABT are possible in a certain category of patients, in particular, in patients with rapid clinical response, as well as after the adequate surgical source control of infection in case of abdominal / urinary sepsis;

procalcitonin levels can be used to assess the duration of $\mathrm{ABT}$ in patients with sepsis.

MM Levy and co-authors [16] have noted a declining trend in sepsis mortality over the past few years following the introduction of a state mandate that requires hospitals to adhere to the sepsis management protocol. The mandate regulates the development and approval of treatment protocols, as well as the obligation to report the treatment outcomes and mortality rates in patients with sepsis. Medical facilities can adapt the protocols to their needs, but they must include the following items: three-hour protocol (all critically ill with sepsis): administration of antibiotics and measurement of lactate levels within 3 hours after diagnosis of "sepsis" with blood sampling before starting antibiotics; six-hour protocol (for septic shock: systolic blood pressure less than $90 \mathrm{~mm} \mathrm{Hg}$ or lactate level greater than $4 \mathrm{mmol} /$
1): intravenous bolus ( $\left.300 \mathrm{~cm}^{3} / \mathrm{kg}\right)$, vasopressors in refractory hypotension, re-determination of lactate level within $6 \mathrm{~h}$ after start of the protocol.

To evaluate the results of the initiative, data from 91,357 adult patients with sepsis and septic shock were analyzed in 183 hospitals during 2014-2016 yrs. Among patients treated in accordance to the protocol, the mortality rate have decreased from 28.8 to $24.4 \%$, what corresponds to the absolute reduction in mortality by $4.4 \%$ and relative - by $15 \%$ during the study period [16].

The choice of optimal doses and routes of administration of antibiotics remains a debatable issue [17]. The metaanalysis by C. H. Chen and co-authors [18] have presented the effectiveness of various ABT programs (intermittent or continuous infusion). It have included 9 randomized controlled trials and 4 retrospective studies, involving 1957 participants. The results of the analysis have showen the overall clinical success rate for continuous and intermittent ABT was 0.675 (95\% confidence interval $0.523-0.870)$. Thus, shorter hospital stays, higher mortality, and longer duration of ABT

Table 3. Recommended ABT regimens* for severe sepsis/septic shock (after Stanford Health Care Antimicrobial Dosing Reference Guide, 2017)

\begin{tabular}{|c|c|c|}
\hline Primary source & $\mathrm{ABT}$ regimens & Alternative ABT scheme \\
\hline $\begin{array}{l}\text { Uncertain or vascular } \\
\text { origin }\end{array}$ & $\begin{array}{c}\text { Piperacillin / tazobactam } 4.5 \mathrm{~g} \text { IV every } 8 \text { hours } \\
\text { Cefepime } 2.0 \mathrm{~g} \text { IV every } 8 \text { hours } \\
\text { Meropenem } 1.0 \mathrm{~g} \text { IV every } 8 \text { hours (at the risk of ESBL) } \\
\text { Aztreonam } 2.0 \mathrm{~g} \text { intravenously every } 8 \text { hours }\end{array}$ & $\begin{array}{l}\text { Vancomycin } 15 \mathrm{mg} / \mathrm{kg} \\
\text { Linezolid } 600 \mathrm{mg} \text { IV every } 12 \text { hours (at risk of VRI) }\end{array}$ \\
\hline Pneumonia & $\begin{array}{c}\text { Piperacillin / tazobactam } 4.5 \mathrm{~g} \text { IV every } 8 \text { hours } \\
\text { Meropenem } 1.0 \mathrm{~g} \text { IV every } 8 \text { hours (at the risk of ESBL) } \\
\text { Cefepime } 2.0 \mathrm{~g} \text { IV every } 8 \text { hours } \\
\text { Aztreonam } 2.0 \mathrm{~g} \text { IV every } 8 \text { hours }\end{array}$ & $\begin{array}{l}\text { Vancomycin } 15 \mathrm{mg} / \mathrm{kg} \\
\text { Linezolid } 600 \mathrm{mg} \text { IV every } 12 \text { hours }+ \\
\text { levofloxacin } 750 \mathrm{mg} \text { IV every } 24 \text { hours } \\
\text { If you are allergic to fluoroquinolones: } \\
\text { azithromycin } 500 \mathrm{mg} \text { IV every } 24 \mathrm{~h}+ \\
\text { tobramycin } 7 \mathrm{mg} / \mathrm{kg} \text { IV every } 24 \text { hours } \\
\text { at risk of infection Ps. aeruginosae }\end{array}$ \\
\hline Urinary tract infection & $\begin{array}{c}\text { Piperacillin / tazobactam } 4.5 \mathrm{~g} \text { IV every } 8 \text { hours } \\
\text { Meropenem } 1.0 \mathrm{~g} \text { IV every } 8 \mathrm{~h} \text { (at risk of ESBL) } \\
\text { Aztreonam } 2.0 \mathrm{~g} \mathrm{IV} \text { every } 8 \text { hours }\end{array}$ & $\begin{array}{l}\text { Vancomycin } 15 \mathrm{mg} / \mathrm{kg} \\
\text { Linezolid } 600 \mathrm{mg} \text { IV every } 12 \text { hours (at risk of VRI) }\end{array}$ \\
\hline $\begin{array}{l}\text { Intra-abdominal } \\
\text { infection }\end{array}$ & $\begin{array}{c}\text { Piperacillin / tazobactam } 4.5 \mathrm{~g} \text { IV every } 8 \text { hours } \\
\text { Meropenem } 1.0 \mathrm{~g} \text { IV every } 8 \mathrm{~h} \text { (at risk of ESBL) } \\
\text { Cefepime } 2.0 \mathrm{~g} \text { IV every } 8 \mathrm{~h}+ \\
\text { metronidazole } 500 \mathrm{mg} \text { IV every } 8 \text { hours } \\
\text { Aztreonam } 2.0 \mathrm{~g} \text { IV every } 8 \text { hours }+ \\
\text { metronidazole } 500 \mathrm{mg} \text { IV every } 8 \text { hours }\end{array}$ & $\begin{array}{l}\text { Vancomycin } 15 \mathrm{mg} / \mathrm{kg} \\
\text { Linezolid } 600 \mathrm{mg} \text { IV every } 12 \text { hours (at risk of VRI) }\end{array}$ \\
\hline $\begin{array}{l}\text { Skin / soft tissue } \\
\text { infection }\end{array}$ & Vancomycin $15 \mathrm{mg} / \mathrm{kg}$ & Cefazolin $2 \mathrm{~g}$ IV every 8 hours \\
\hline $\begin{array}{l}\text { Skin / soft tissue } \\
\text { infection with } \\
\text { additional risk factors }\end{array}$ & $\begin{array}{c}\text { Piperacillin / tazobactam } 4.5 \mathrm{~g} \mathrm{IV} \text { every } 8 \text { hours } \\
\text { Meropenem } 1.0 \mathrm{~g} \text { IV every } 8 \mathrm{~h} \text { (at risk of ESBL) } \\
\text { Cefepime } 2.0 \mathrm{~g} \mathrm{IV} \mathrm{every} 8 \mathrm{~h}+ \\
\text { metronidazole } 500 \mathrm{mg} \text { IV every } 8 \text { hours } \\
\text { Aztreonam } 2.0 \mathrm{~g} \text { IV every } 8 \text { hours }+ \\
\text { metronidazole } 500 \mathrm{mg} \text { IV every } 8 \text { hours }\end{array}$ & Vancomycin $15 \mathrm{mg} / \mathrm{kg}$ \\
\hline $\begin{array}{l}\text { Necrotizing fasciitis, } \\
\text { clostridial gas gangrene }\end{array}$ & $\begin{array}{c}\text { Piperacillin / tazobactam } 4.5 \mathrm{~g} \text { IV every } 8 \text { hours } \\
\text { Meropenem } 1.0 \mathrm{~g} \text { IV every } 8 \mathrm{~h} \text { (at risk of ESBL) } \\
\text { Cefepime } 2.0 \mathrm{~g} \mathrm{IV} \mathrm{every} 8 \mathrm{~h}+ \\
\text { metronidazole } 500 \mathrm{mg} \text { IV every } 8 \text { hours } \\
\text { Aztreonam } 2.0 \mathrm{~g} \text { IV every } 8 \text { hours }+ \\
\text { metronidazole } 500 \mathrm{mg} \text { IV every } 8 \text { hours }\end{array}$ & $\begin{array}{l}\text { Vancomycin } 15 \mathrm{mg} / \mathrm{kg} \\
\text { Linezolid } 600 \mathrm{mg} \text { IV every } 12 \text { hours (at risk of VRI) }\end{array}$ \\
\hline $\begin{array}{l}\text { Spontaneous bacterial } \\
\text { meningitis }\end{array}$ & Ceftriaxone 2 g IV every 12 hours & Vancomycin $15 \mathrm{mg} / \mathrm{kg}$ \\
\hline Note. & $\begin{array}{l}\text { ed schemes are recommended for use in nosocom } \\
\text { SBL - extended-spectrum beta-lactamases, VRI }\end{array}$ & $\begin{array}{l}\text { ns or in immunosuppressed patients; in / in - } \\
\text { omycin-resistant infection. }\end{array}$ \\
\hline
\end{tabular}


were observed in patients, receiving intermittent infusions, but the differences were not statistically significant due to the limited number of patients included in the study. The authors have noted, that the data obtained are insufficient to unequivocally recommend continuous infusion of antibiotics as opposed to standard periodic infusions in the treatment of sepsis, and further research in this area should be conducted to finalize recommendations.

Beta-lactam antibiotics show a time-dependent mechanism of action, and there is evidence of improved treatment outcomes when these drugs are administered by continuous infusion as opposed to the standard intermittent regimen [19]. The study (BLING) is currently being conducted in many intensive care units in clinics of Australia, the United Kingdom, Belgium and some other countries, with expected completion date in 2021. The researchers plan to cover 7,000 patients with sepsis whose treatment program involves the use of one of two betalactam antibiotics (piperacillin-tazobactam or meropenem) with continuous or intermittent infusion. The primary outcome of the study will be the mortality rate within 90 days of randomization. Secondary results include evaluation of treatment results on the 14th day after randomization, the need to change the ABT regimen, the presence of infection with multidrug-resistant bacteria up to 14 days after randomization, mortality from the underlying disease [17].

Now there are no new classes of antibiotics in the arsenal of drugs available. New variations of the known betalactam drugs, protected by beta-lactamase inhibitors (ceftalozan-tazobactam, ceftazim-avibactam, ceftarolineavibactam), aztreon-avibactam, imipenem-relebactam, and meropenem, continue to be used (Table 3).

Applicationof the third-generation cephalosporins combined with beta-lactamase inhibitors remains the basis of ABT in sepsis. New treatments, such as monoclonal antibodies, peptide and bacteriophage therapy, are under investigation and are still far from practice. Therefore, the use of existing drugs should be rational and balanced [20].

The therapeutic monitoring of antibiotics with the aim to determine the toxicity of aminoglycosides and glycopeptides have allowed the introduction of easy-touse immunoassays to adjust the drugs dusing in ABT sepsis [19]. Patients in critical condition often need different doses, which significantly differ from the standard ones, approved at the time of a drug registration. The importance of correct dosing of antibiotics is difficult to overestimate, because otherwise there is a risk of re-growth of bacteria with a predominance of resistant flora $[21,22]$. The principle of standard dosing of antibiotics should be abandoned and replaced by an individual approach, which takes into account the impact of pathophysiological processes in the patient'organism with sepsis on the pharmacokinetics of these drugs. Another argument for the individualization of $\mathrm{ABT}$ is the threat of an increase in the number of patients with infections, caused by multidrug-resistant strains in the intensive care unit. To improve the effectiveness of
ABT, the teams of specialists are being created, which is a sustainable area of development in the world's leading medical institutions. Interdisciplinary cooperation of the team with the infectious diseases specialists, microbiologists and clinical pharmacists will not only ensure the rational use of antibiotics, but would have a positive effect on the final result of ABT as well [13, 22, 23].

\section{Conclusions}

Sepsis as a complex pathological disorder of human organism requires the global priority, continues to become the focus of contemporary medicine and is the subject of scientific research. Despite some progress achieved, a shortterm mortality remains high, with an increase in long-term morbidity and mortality in patients with sepsis.

Prescribing antibiotics is an important component of initial therapy for sepsis, early adequate ABT is crucial for the end result of the treatment. In sepsis, antibiotics should be administered intravenously only, selecting the maximum doses and adequate dosing regimens.

The promising area is the use of continuous infusions of antibiotics. Patients in critical condition often require personalized dosage of antibiotics due to changes in the pharmacokinetics of drugs in sepsis.

The team's interdisciplinary collaboration with infectious disease specialists, microbiologists and clinical pharmacists not only leads to the rational use of antibiotics, but also has a positive effect on the outcome of treatment as a whole.

Financing. Used funds of an individual.

Participation of autbors. Vashchuk VV - concept and design of the research, text writing, editing; Andryushchenko VP - text editing; Kyryk TP - literature review, text writing; Kushnirchuk MI - elaboration of literature, writing of the text; Baidala RP, Ivanyshyn AZ, Khomchenko TV elaboration of literature, assistance in writing the text.

Conflict of interest. None.

\section{References}

1. Hecker A, Reichert M, Reuß CJ, Schmoch T, Riedel JG, Schneck E, et al. Intra-abdominal sepsis: new definitions and current clinical standards. Langenbecks Arch Surg. 2019 May;404(3):257-71. doi: 10.1007/s00423-019-01752-7. Epub 2019 Jan 26. PMID: 30685836.

2. Duda AK, Krasnov MI. Modern aspects of the empirical treatment of sepsis. Disease and antibiotics. 2013;(1):7-12. Russian.

3. Barantsevich E, Barantsevich N, Rybkova N, Churkina I, Pestova N, Karpenko M. Etiological agents of bacterial sepsis in a newly constructed medical center in Saint Petersburg, Russia. Critical Care. 2011;15(Suppl 3):P45. Russian. doi:10.1186/cc10414.

4. Rudnov VA, Kulabukhov VV. Sepsis-3: updated main definitions, potential problems and next practical steps. Messenger of anesthesiology and resuscitation. 2016;13(4):4-11. Russian. doi. org/10.21292/2078-5658-2016-13-4-4-11

5. Shapoval SD, Tribushnyi OV, Savon IL. Lethality in patients with complicated diabetic foot syndrome and signs of sepsis in 
accordance to recommendations "Sepsis-3". Klin Khir. 2018 March;85(3):33-3. Ukranian. doi:10.26779/25221396.2018.03.33.

6. Perner A, Gordon AC, De Backer D, Dimopoulos G, Russell JA, Lipman J, et al. Sepsis: frontiers in diagnosis, resuscitation and antibiotic therapy. Intensive Care Med. 2016 Dec;42(12):1958-69. doi: 10.1007/s00134-016-4577-z. Epub 2016 Oct 1. PMID: 27695884.

7. Allison MG, Heil EL, Hayes BD. Appropriate Antibiotic Therapy. Emerg Med Clin North Am. 2017 Feb;35(1):25-42. doi: 10.1016/j. emc.2016.08.003. PMID: 27908336.

8. Andersson M, Östholm-Balkhed Å, Fredrikson M, Holmbom M, Hällgren A, Berg S, et al. Delay of appropriate antibiotic treatment is associated with high mortality in patients with community-onset sepsis in a Swedish setting. Eur J Clin Microbiol Infect Dis. 2019 Jul;38(7):1223-34. doi: 10.1007/s10096-019-03529-8. Epub 2019 Mar 25. PMID: 30911928; PMCID: PMC6570779.

9. Cudini D, Smith K, Bernard S, Stephenson M, Andrew E, Cameron $\mathrm{P}$, et al. Can pre-hospital administration reduce time to initial antibiotic therapy in septic patients? Emerg Med Australas. 2019 Aug;31(4):669-72. doi: 10.1111/1742-6723.13282. Epub 2019 Mar 28. PMID: 30924278.

10. Ferrer R, Martin-Loeches I, Phillips G, Osborn TM, Townsend S, Dellinger RP, et al. Empiric antibiotic treatment reduces mortality in severe sepsis and septic shock from the first hour: results from a guideline-based performance improvement program. Crit Care Med. 2014 Aug;42(8):1749-55. doi: 10.1097/CCM.0000000000000330. PMID: 24717459.

11. Buckman SA, Turnbull IR, Mazuski JE. Empiric Antibiotics for Sepsis. Surg Infect (Larchmt). 2018 Feb/Mar;19(2):147-54. doi: 10.1089/sur.2017.282. Epub 2018 Jan 17. PMID: 29341844.

12. Napolitano LM. Sepsis 2018: Definitions and Guideline Changes. Surg Infect (Larchmt). 2018 Feb/Mar;19(2):117-25. doi: 10.1089/ sur.2017.278. PMID: 29447109.

13. Richter DC, Heininger A, Brenner T, Hochreiter M, Bernhard M, Briegel J, et al. Bacterial sepsis : Diagnostics and calculated antibiotic therapy. Anaesthesist. 2019 Feb;68(Suppl 1):40-62. doi: 10.1007/s00101-017-0396-z. PMID: 29383395.

14. Rhodes A, Evans LE, Alhazzani W, Levy MM, Antonelli M, Ferrer R, et al. Surviving Sepsis Campaign: International Guidelines for Management of Sepsis and Septic Shock: 2016. Intensive Care Med. 2017 Mar;43(3):304-77. doi: 10.1007/s00134-017-4683-6. Epub 2017 Jan 18. PMID: 28101605.

15. Fernando SM, Rochwerg B, Seely AJE. Clinical implications of the Third International Consensus Definitions for Sepsis and Septic Shock (Sepsis-3). CMAJ. 2018 Sep 10;190(36):E1058-E9. doi: 10.1503/cmaj.170149. PMID: 30201611; PMCID: PMC6131078.
16. Levy MM, Gesten FC, Phillips GS, Terry KM, Seymour CW, Prescott HC, et al. Mortality Changes Associated with Mandated Public Reporting for Sepsis. The Results of the New York State Initiative. Am J Respir Crit Care Med. 2018 Dec 1;198(11):140612. doi: 10.1164/rccm.201712-2545OC. PMID: 30189749; PMCID: PMC6290949.

17. Lipman J, Brett SJ, De Waele JJ, Cotta MO, Davis JS, Finfer S, et al. A protocol for a phase 3 multicentre randomised controlled trial of continuous versus intermittent $\beta$-lactam antibiotic infusion in critically ill patients with sepsis: BLING III. Crit Care Resusc. 2019 Mar;21(1):63-8. PMID: 30857514.

18. Chen CH, Chen YM, Chang YJ, Wang SH, Chang CY, Yen HC. Continuous versus intermittent infusions of antibiotics for the treatment of infectious diseases: Meta-analysis and systematic review. Medicine (Baltimore). 2019 Mar;98(10):e14632. doi: 10.1097/ MD.0000000000014632. PMID: 30855448; PMCID: PMC6417613.

19. Wong G, Brinkman A, Benefield RJ, Carlier M, De Waele JJ, El Helali N, et al. An international, multicentre survey of $\beta$-lactam antibiotic therapeutic drug monitoring practice in intensive care units. J Antimicrob Chemother. 2014 May;69(5):1416-23. doi: 10.1093/ jac/dkt523. Epub 2014 Jan 16. PMID: 24443514.

20. McHugh L, Seldon TA, Brandon RA, Kirk JT, Rapisarda A, Sutherland AJ, et al. A Molecular Host Response Assay to Discriminate Between Sepsis and Infection-Negative Systemic Inflammation in Critically Ill Patients: Discovery and Validation in Independent Cohorts. PLoS Med. 2015 Dec 8;12(12):e1001916. doi: 10.1371/ journal.pmed.1001916. PMID: 26645559; PMCID: PMC4672921.

21. Bergen PJ, Bulitta JB, Kirkpatrick CM, Rogers KE, McGregor MJ, Wallis SC, et al. Effect of different renal function on antibacterial effects of piperacillin against Pseudomonas aeruginosa evaluated via the hollow-fibre infection model and mechanism-based modelling. J Antimicrob Chemother. 2016 Sep;71(9):2509-20. doi: 10.1093/ jac/dkw153. Epub 2016 May 26. PMID: 27231278.

22. Timsit JF, Ruppe E, Ferrer R. Focus on sepsis: new concepts and findings in sepsis care. Intensive Care Med. 2018 Nov;44(11):19979. doi: 10.1007/s00134-018-5406-3. Epub 2018 Oct 10. PMID: 30306194.

23. Nishida O, Ogura H, Egi M, Fujishima S, Hayashi Y, Iba T, et al. The Japanese Clinical Practice Guidelines for Management of Sepsis and Septic Shock 2016 (J-SSCG 2016). Acute Med Surg. 2018 Feb 5;5(1):3-89. doi: 10.1002/ams2.322. PMID: 29445505; PMCID: PMC5797842.

Received: 16.11.2020 